\title{
The Effect of Usefulness, Ease of Use, Risk, and Trust to Behavioral Intention in the Use of Internet Banking
}

\author{
Robino Indan*, Rio Andika, Muhammad Ridwan, and Robby Dharma \\ Universitas Putra Indonesia "YPTK" \\ Padang, Sumatera Barat, Indonesia \\ *robino@upiyptk.ac.id
}

Received 02 February 2016; Revised 13 March 2016; Accepted 21 June 2016

\begin{abstract}
Recently information technology is one of the vital elements in human daily activity supports. One example of information technology measurement is based on the Technology Acceptance Model (TAM), which is an information system that shows how users come to accept and use the technology. Usefulness and Ease of Use are the main reasons that would predispose a person to use such technology. The TAM is also applied to the use of Internet Banking, but there are some more factors that will affect the Behavior Intention in using the Internet Banking including Risk and Trust. The aim of this study is to prove the hypothesis of the variables that affect the Behavior Intention. Research variables were measured using a questionnaire that is processed with SPSS software. The results showed that the four variables studied positive influence on Behavior Intention in the use of Internet Banking.
\end{abstract}

Keywords: Internet banking; Usefulness; Ease of use; Risk; Trust; Behavior intention.

\section{Introduction}

The information system theory called Technology Acceptance Model (TAM) which shows how users come to accept and use the technology. This model shows that when the user is presented with a new technology, a number of factors influence their decisions about how and when they will use it. At first the theory advanced by Davis (1989) [1] where the factor Usefulness and Ease of Use are the main reasons that would predispose a person to use such technology. Internet Banking implies the provision of banking products and services through electronic delivery channels. Electronic banking has been around for some time in the form of automatic teller machines (ATM) and transactions via the telephone. As the times of the all internet, now has available a new way to facilitate banking transactions for customers and also to facilitate the operations for the bank. For customers, the Internet offers access to a faster, more convenient and available around the clock regardless of customer location (Chavan, 2013). Chavan (2013) also found the use of Internet Banking has significantly reduced the physical cost of banking operations. Advances in information technology have cut the cost of information processing, while the internet has facilitated the transmission. Across the world, electronic banking services, whether delivered online or through other mechanisms, has spread rapidly in recent years. The advantages of the use of Internet Banking are not only to customers but also to the bank. Where benefits for customers include the customers do not need to come to the bank to various questions regarding their account, customers can save time and travel costs in achieving the bank, customers can perform these activities anytime and anywhere, customers can pay their bills on time so that it can be protected from penalties, and to see more detailed transaction history (Mishra and Sahoo, 2013). While profits for the bank, among others, the bank can save time and labor costs in order to be used for other activities, the bank can take advantage of the benefits in the form of commission from the cellular companies, banks become more competitive advantage compared to other banks 


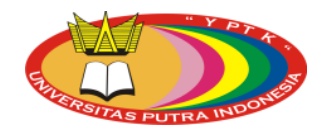

which do not provide This service, as well as to allow the bank to reduce other costs. But the lack of Internet Banking to its customers is the customer can not directly convey their complaints.

Internet Banking has been used as an alternative technology where it is still a force to Malaysia in general as computer literacy (Amin, 2007). Therefore, in order to promote the use of Internet Banking, several situations must be met. First, it is important to create trust between individuals of the system by providing sufficient information and Useful for critical thinking in order to avoid or minimize risk. The second is predictable in the future that the central bank provides Internet banking to promote the use of the system and provides a facility to serve the consumer complaints. Third, banks should support Usefulness of the system so that users are aware and believe about the Usefulness of the system. In India, Kesharwani and Bisht (2012) has research with survey by Internet and Mobile Association of India (IAMAI), after 2009 IAMAI did a recent study that found that only about 12 percent of online users prefer Internet Banking as banking channels are smaller than in 2008 at which time 20 percent.

Research related to Internet Banking previously, they had been carried out in Indonesia by Koo et al. (2013). However, it is more towards a comparison between the use of a PC or laptop with mobile banking using smartphones. These findings are the use of these two tools is similar, but each person's mostly use both of these tools. Where smartphones are used in urgent circumstances while PC or laptop if they want to see more detail about the transaction history. It drives Koo et al. (2013) conducted a study is due to see opinions from Jardine (2009) which says that the low interest of the people of Indonesia to the development of Information Technology. The number of subscribers and internet users who always showed significant increase from year to year has becoming the drivers of the use of Internet banking and mobile banking in Indonesia. Growth in the number of Internet users in Indonesia, seen from a survey organized by the Association of Indonesian Internet Service Provider (APJII) reveals that the number of Internet users in Indonesia in 2012 reached 63 million people or 24.23 percent of the total population of the country. And that figure is predicted to rise about 30 percent to 82 million users and continues to grow to 107 million in 2014 and 139 million, or 50 percent of the total population in 2015. From the results of a survey conducted by the Association of Indonesian Internet Service Provider (APJII) regarding the use of internet banking, activities are mostly done by the users of internet banking is to see balance information and the next activity is often done is to transfer funds and to purchase, such as a pulse or ticket purchase. Other activities performed by the users of the Internet Banking is to make regular bill payments, check transaction history, as well as to check the status of the transaction.

Therefore, this study presents an analysis to see how the influence of usefulness, ease of use, risk, and trust on behavior intention in the use of internet banking. This study also presents hypothesis of the above variables that affect the behavior intention. Research variables were measured using a questionnaire that is processed with SPSS software.

The rest of this paper is organized as follow. Section 2 describes analysis on existing work. Section 3 describes proposed hypotheses and methodology. Section 4 presents results and following by discussion. Finally, the conclusion of this work is presented in Section 5.

\section{Related Works}

There are four factors that affect the Behavior Intention to Use Internet Banking.

\subsection{Usefulness}

Davis (1989) Usefulness factor defines as "a level in which a person believes that using the system can improve its performance in the work". Thus it can be concluded that the usefulness factor is a belief about the decision-making process. Usefulness positive and significant influences on the use of information systems and is a degree to which a person believes that the use of a particular technology will increase the person's job performance. If it is associated with bank customers, this means how the benefits that customer finds against the whole idea of using the application, and how many found to contribute to the overall performance and the look of the efficiency factor. Innovation is considered easier to use have a higher likelihood to be accepted and used by potential users (Montazemi and Saremi, 2013). Usefulness is the extent to which a person believes that 
using a technology will improve its performance, and it is an assertion of the decision-making process. If a person feels confident that the system is useful, then he will use it. Conversely, if a person feels confident that the information system is less useful, then he will not use it. Therefore, the level of benefit for accessing the Internet Banking, will affect customers' interest in using the Internet Banking system (Gerrard and Devlin, 2006). According to Chavan (2013) customers Internet Banking user will get some major advantages include reducing the cost of accessing and using banking services, increased convenience and time savings, the transaction can be done 24 hours a day without the need for physical interaction with the bank, fast access, comfort because all banking transactions can be done from home or office or where the customer is browsing, the speed factor, and freedom because customers can conduct all the transactions that they need also see the transaction history from when to when unnoticed by others.

\subsection{Ease of Use}

Ease of Use as the degree to which a person believes that the use of information systems is easy and requires no effort from the wearer to be done (Davis, 1989). By definition it can be seen that the Ease of Use is also a belief about the decision-making process. If someone believes that the information system is easy to use then that person will use it. Additionally Ease of Use is also defined that the extent to which a person believes that using a technology would be free of effort. By definition it can be seen that the perception Ease of Use is an assertion about the decisionmaking process. If a person feels confident that the system is easy to use information, then he will use it. Ease of use of facilities greatly affects the initial expectations of the consumer intentions (Montazemi and Saremi, 2013). In addition, consumers also urged the little effort in the use of technology. Perception Ease of Use provide some indicator of an information system (including Internet Banking) which includes time efficiency in the use, zoom the site easy to understand, add skills to use, and easy to learn. Intensity of use and the interaction between users and systems can also indicate factors Ease of Use. A frequently used system shows that the system is better known, and more easily used by users. Perception Ease of Use will reduce business customers in studying the origins of the behavior of transactions through Internet Banking. Ease of Use also gives an indication that the information system users can work more easily compared to the works without the use of information systems. Thus, when the services are easy to use Internet Banking perceived by consumers, such services will also be useful perceived (Davis, 1989). Relating to the use of internet banking, if an online service that is found to be very difficult and complicated to use, the customer is very likely to make transactions with more traditional manner.

\subsection{Risk}

Risk is a perception of the customers on uncertainty and unintended consequences in the conduct of activities (Safeena et al., 2013) in his research states that risk factors have a significant and positive effect on the customer to accept the online banking system. This risk is closely linked to security and privacy issues (Lichtenstein and Williamson, 2006). Therefore, researchers can assume that the customer wants Risk factors are minimal. Risk is a state of uncertainty which considered people to decide or not to do transactions online. Risk of Internet Banking is more high level of uncertainty (transaction failures or technical error) when compared to conventional transactions and is regarded as the uncertainty associated with the outcome of a decision. In the literature of e-commerce, Risk divided into two categories, namely the risk of the transaction and the risk of the product. Risk refers to the uncertainty of the purchase of the product will meet the acceptance measurements in the result or purpose of purchase. Transaction risk is the uncertainty of something unexpected and unfavorable throughout the transaction process. In this case the risk covered is associated with the transaction.

According to Susanto et al. (2013) differences in customer expectations Indonesia with South Korean customers against the risk of Internet Banking in Indonesia is that it is more concerned with security while in Korea is more concerned with privacy. The risks of the transaction are including verification, privacy, and security. Privacy risk refers to the possible theft of personal information relating to the safety of the data that can be viewed with the Internet. Risk is a state of 


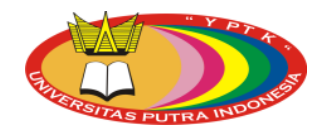

uncertainty where considered people to decide or not to do transactions online. One will consider the distance and impersonal atmosphere in online transactions and global infrastructure that contains elements risk. Risk is defined as a subjective estimate of the consumer to suffer losses in receiving the desired outcomes (Pavlou and Featherman, 2003). According to Dowling and Staelin (1994), if the risk was increased from mere information to the product purchasing decisions (transaction), the risks associated with trust (confidence). In this study, risk indicators seen from the actions taken by banks to minimize the risk of the use of internet banking, are expected to actions taken by banks to minimize the risk will have a positive impact on consumer intentions to use the technology offered. Consumer confidence in the services offered will affect the interest of consumers to take advantage of the service. Tan and Teo (2000) argues that the lower the perceived risk in using Internet Banking, the more likely that Internet banking will be in demand. Fraud in the internet world may negatively affect customer opinion about the safety of the Internet (Muzividzi et al., 2013).

\subsection{Trust}

Trust is the foundation of the business. Build confidence in the long-term relationship with customers is an important factor for creating customer loyalty. This belief not just be recognized by the other parties / business partners, but must be built from scratch and can be proven. When consumers trust a company, they would rather make repeat purchases and share personal information that is valuable to the company Prasaranphanich (2007). Investments in the form of money are very influential with the Trust (Verhagen and Heijden, 2004) especially in this case is a process transactions made with cyber-risk facilities to investment money owned by the user of the facility. Trust is the willingness (willingness) of individuals to rely on other parties involved in the exchange because people have confidence (confidence) to another party. When one party has confidence (confidence) that the other parties involved in the exchange have the reliability and integrity, it can be said there is Trust. Choudhury and Ahmad (2011) defines trust is a trust given to the other party in the relationship transaction based on a belief that the person who is believed to have all the obligations as well as expected. Consumer confidence according to Brown et al. (2002) are all the knowledge possessed by consumers and all conclusions made consumers about the objects, attributes, and benefits. In the case of the use of Internet Banking, Muzividzi et al. (2013) says that the bank must ensure its customers first so that customers can feel safe using the Internet Banking facilities. For the problem of loyalty to the bank where they become customers, Susanto et al. (2013) found customer Indonesia and South Korea have differences, where Indonesian customers are more concerned with the trust and customer satisfaction in order to be loyal to the bank customer while South Korea is more concerned with the commitment of the bank. In most economic activities, the Trust is an important factor that allows some uncertainty. Included also in the case where the Internet Banking is a sector which is considered high risk. Montazemi and Saremi (2013) argued that the Trust to use Internet Banking Internet Banking influenced by itself and also by the physical factors of the bank.

\subsection{Behavior Intention}

Behavior Intention means how strong the people have interest to do something (Yi and Hwang, 2003). One important thing in information systems research how and why individuals accept and adopt new information technologies (Agarwal and Karahanna, 2000). Behavior Intention refers to factors that can hinder the performance of the behavior. This definition covers two components. The first is self-efficacy and self-confidence is defined as an individual within or ability to perform the behavior. The second component is the "facilitating" that guarantees the availability of the resources needed to engage in behavior (Triandis 1989). Self-efficacy is predicting intention to use a wide range of technologically advanced products. Thus, an individual's confidence in the skills in using computers and the Internet are more likely to adopt Internet Banking. This is because the individual is comfortable in using innovation. Tan and Theo (2000) found greater self-efficacy to use Internet Banking, the more likely that Internet banking will be adopted. This second component refers to the ease of access to technological resources and infrastructure, which as a 
supporting technology infrastructure becomes easy and available, internet commerce applications such as banking services will also become more feasible. As a result, Internet users will be expected to be more inclined to adopt Internet Banking. Tan and Theo (2000) also argues that the greater the level of perceived technology support Internet Banking, the more likely that Internet banking will be adopted.

\section{Proposed Methodology}

This research included in hypothesis testing which aims to explain the nature of certain relationships, or determine the differences between groups or freedom (independence) of two or more factors in a situation. The type of investigation is based on a causal study, since we want to find the cause of one or more particular phenomenon. As well as the unit of analysis in this study is an individual because it will only see the data that is collected from each individual and treat each respondent's response as a data source individually. In this study, the authors chose the location in one of the private bank in Jakarta. Meanwhile the object of this paper is the bank customers.

\section{Result and Discussions}

This section presents result obtained and following by discussions.

\subsection{Data Collection}

The sample in this study was all clients of a private bank in Jakarta, which amounted to 100 people. Sampling was done in a random way (simple random sampling), in which every member of the population is given an equal opportunity to be a sample. By conduction random technique, since the sample collection is done by mixing the subjects in the population. Therefore, all subjects deemed to have the same right to the opportunity to be selected into the sample. In this study, data collection techniques done field research is to conduct questionnaires to customers of the bank. Distributing questionnaires conducted by distributing hardcopy and online surveys within 1 month. Profile of respondents need to be studied include sex, age, education, past work, long as a customer, and the average monthly balance. This identification is done in order to know the general characteristics of the respondent.

Based on data obtained from 100 respondents, respondents gender ratio of male and female are almost the same as many men as 52 people or $52 \%$, while the women as much as many as 48 people or $48 \%$. In terms of age, the majority of respondents are aged over 50 years, which is as many as 44 people or $44 \%$, with the education level is the majority of high school graduates that as many as 48 people or $48 \%$. From this work the majority of respondents are working as selfemployed with the number 72 or $72 \%$. Most of the respondents who are the customers who have become customers in the bank within a period of over two years, which is as many as 54 people or $54 \%$. While the average monthly balance of the majority of respondents is IDR 1 million to IDR 10 million with a total of 72 or $72 \%$. Table 1 below shows profile of respondents.

Table 1: Profile of Respondents

\begin{tabular}{|l|l|c|c|}
\hline Category & \multicolumn{1}{|c|}{ Characteristic } & Respondents & Percentage (\%) \\
\hline \multirow{3}{*}{ Gender } & Male & 52 & 52 \\
\cline { 2 - 4 } & Female & 48 & 48 \\
\hline \multirow{4}{*}{ Age (years) } & $17-30$ & 16 & 16 \\
\cline { 2 - 4 } & $31-50$ & 40 & 40 \\
\cline { 2 - 4 } & $>50$ & 44 & 44 \\
\hline \multirow{5}{*}{ Education } & High School & 48 & 48 \\
\cline { 2 - 4 } & Bachelor Degree & 32 & 32 \\
\cline { 2 - 4 } & Master and & 3 & 3 \\
\cline { 2 - 4 } & Doctoral Degree & 17 & 17 \\
\cline { 2 - 4 } & Others & \multicolumn{2}{|c}{} \\
\hline
\end{tabular}




\begin{tabular}{|l|l|c|c|}
\multirow{5}{*}{ Occupation } & $\begin{array}{l}\text { Student / } \\
\text { Undergraduate } \\
\text { Student }\end{array}$ & 0 & 0 \\
\cline { 2 - 4 } & Employee & 28 & 28 \\
\cline { 2 - 4 } & Entrepreneur & 72 & 72 \\
\hline \multirow{3}{*}{$\begin{array}{l}\text { Old Being } \\
\text { Customer }\end{array}$} & $<6$ months & 5 & 5 \\
\cline { 2 - 4 } & $6-12$ months & 24 & 24 \\
\cline { 2 - 4 } & $1-2$ years & 17 & 17 \\
\cline { 2 - 4 } & $>2$ years & 54 & 54 \\
\hline Average & $<1$ Million & 2 & 2 \\
\cline { 2 - 4 } $\begin{array}{l}\text { Monthly } \\
\text { Balance } \\
\text { (IDR) }\end{array}$ & $1-10$ Millions & 72 & 72 \\
\cline { 2 - 4 } & $10-100$ Millions & 26 & 0 \\
\cline { 2 - 4 } & $>100$ Millions & 0 & 0 \\
\hline
\end{tabular}

\subsection{Variables Research and Measurement}

Measurement model here is using validity and reliability. Validity test used to measure whether a legitimate or valid questionnaires. A questionnaire is said to be valid if the questions on the questionnaire were able to express something that will be measured by the questionnaire. The validity of use is tested by using a correlation coefficient between scores grain instrument with a total score (r-count) through the technique of Pearson Product Moment Correlation. Analysis was performed on whole grains instrument. Criteria testing is done by comparing $r$-count of the results of calculations that must be greater than $r$-table $(r$-count $>r$-table) so that the grain valid instrument. But if $r$ is calculated from the calculation result is smaller than $r$-table $(r$-count $<r$ table) then the item is considered invalid instrument so it can not be used for research. Correlation calculations performed using SPSS.

Test reliability is a term used to indicate the extent to which relatively consistent measurement results when the measurement was repeated twice or more. The reliability of the data in this study is using two provisions i.e. the Inter-Item Consistency Reliability to see Cronbach's Alpha and Construct Reliability (CR). In using Cronbach's alpha and CR, an instrument is said to be reliable if it has a coefficient alpha $(\alpha)$ of 0.6 or more. Reliable values for the instrument are:

a. If the coefficient alpha $(\alpha)$ test is greater than $(\geq) 0.6$, the statements in the questionnaire feasible to use (reliable).

b. If the coefficient alpha $(\alpha)$ test less than $(<) 0.6$, the statements in the questionnaire improperly used (not reliable).

\subsection{Analysis}

Results of the validity and reliability can be seen in Table 2 .

Table 2: Result of the validity and reliability

\begin{tabular}{|c|c|c|c|c|}
\hline Variables and Indicators & $r$-count & $r$-table & $\begin{array}{c}\text { Cronbach's } \\
\text { Alpha }\end{array}$ & $\begin{array}{c}\text { Standard } \\
\text { Values }\end{array}$ \\
\hline $\begin{array}{l}\text { Usefulness } \\
-\quad \text { Internet Banking will enhance my performance in } \\
\text { conducting banking transactions. } \\
\text { - Internet Banking will make it easier for me to carry } \\
\text { out banking transactions. } \\
\text { - I will find the benefits of Internet Banking in doing } \\
\text { my banking transactions. } \\
\text { Internet Banking is able to improve the efficiency } \\
\text { of my banking activities. }\end{array}$ & $\begin{array}{l}0.842 \\
0.901 \\
0.648 \\
0.732\end{array}$ & $\begin{array}{l}0.361 \\
0.361 \\
0.361 \\
0.361\end{array}$ & 0.899 & 0.6 \\
\hline $\begin{array}{l}\text { Ease of Use } \\
\text { - Internet Banking is easy to use. }\end{array}$ & 0.697 & 0.361 & 0.905 & 0.6 \\
\hline
\end{tabular}


- Learning to operate Internet Banking is easy.

- I find it easy to become skilled in using Internet Banking.

- I will find Internet Banking is easy to use.

$\underline{\text { Risk }}$

- I believe the ability of Internet Banking to protect my privacy.

- Using the Internet Banking is a financial security.

- I'm not worried about the security of Internet Banking.

- I believe that the Internet Banking site will do the job properly even if it is not monitored.

\section{Trust}

- I believe that this bank is a reliable bank.

- I believe that this bank can be pledged and committed.

- I believe that the bank considers the customer gains as a top priority.

- I believe that the Internet Banking site will do the job properly even if it is not monitored.

\section{Behavior Intention}

- I intend to use the Internet Banking continuously.

- I would recommend others to use the Internet Banking in the future.

- I will use the Internet Banking in the future.

- I assume that I have access to the Internet Banking system, and therefore I intend to use it.

From the pre-test results in Table 2, for the validity of the results of the test indicate that each item of these five variables are valid, where the results of the count are all the $r$-count greater than $r$ table (0.361). While the results of reliability test is seen that these five variables have a value of Cronbach's Alpha are all value greater than the default value (0.6). Therefore, these five variables can be said to be reliable.

\subsection{Descriptive Statistics}

Descriptive statistics were performed to determine the frequency distribution of respondents as a whole, both in the number of respondents or people, and mean values for each question on each variable and then performed a descriptive discussion. This analysis is used to illustrate the phenomenon of research. In this study, descriptive statistical analysis displays information processed by variations in the average number (mean) and standard deviation of respondents on each item of the five variables. Elaboration of the five variables can be seen in Table 3 .

Table 3: Descriptive statistics

\begin{tabular}{|c|c|c|c|}
\hline Variable & Item & Mean & $\begin{array}{c}\text { Std. } \\
\text { Deviation }\end{array}$ \\
\hline \multirow{3}{*}{$\begin{array}{c}\text { Usefulness } \\
(\mathrm{U})\end{array}$} & $\mathrm{U} 1$ & 3,65 & 1,18 \\
\cline { 2 - 4 } & $\mathrm{U} 2$ & 3,62 & 1,13 \\
\cline { 2 - 4 } & $\mathrm{U} 3$ & 3,58 & 1,2 \\
\hline \multirow{2}{*}{$\begin{array}{c}\text { Ease of Use } \\
(\text { EU) }\end{array}$} & $\mathrm{U} 4$ & 3,64 & 1,21 \\
\cline { 2 - 4 } & $\mathrm{EU} 1$ & 3,48 & 1,23 \\
\hline \multirow{2}{*}{} & 3,34 & 1,28 \\
\hline
\end{tabular}




\begin{tabular}{|c|c|c|c|}
\hline \multirow{4}{*}{} & EU3 & 3,41 & 1,18 \\
\cline { 2 - 4 } & EU4 & 3,41 & 0.98 \\
\hline \multirow{4}{*}{$\begin{array}{c}\text { Risk } \\
(\mathrm{R})\end{array}$} & $\mathrm{R} 1$ & 3,58 & 1,29 \\
\cline { 2 - 4 } & $\mathrm{R} 2$ & 3,82 & 0.99 \\
\cline { 2 - 4 } & $\mathrm{R} 3$ & 3,44 & 1,26 \\
\cline { 2 - 4 } & $\mathrm{R} 4$ & 3,29 & 1,3 \\
\hline \multirow{4}{*}{$\begin{array}{c}\text { Trust } \\
(\mathrm{T})\end{array}$} & $\mathrm{T} 1$ & 3,41 & 1,06 \\
\cline { 2 - 4 } & $\mathrm{T} 2$ & 4,06 & 0.84 \\
\cline { 2 - 4 } & $\mathrm{T} 3$ & 4,13 & 0.86 \\
\cline { 2 - 4 } & $\mathrm{T} 4$ & 4,17 & 0.93 \\
\hline \multirow{3}{*}{$\begin{array}{c}\text { Behavior } \\
\text { Intention } \\
(\text { BI) }\end{array}$} & $\mathrm{BI} 1$ & 3,89 & 0.94 \\
\cline { 2 - 4 } & $\mathrm{BI} 2$ & 3,75 & 0.92 \\
\cline { 2 - 4 } & $\mathrm{BI}$ & 3,59 & 1,01 \\
\cline { 2 - 4 } & $\mathrm{BI} 4$ & 3,68 & 1,04 \\
\hline
\end{tabular}

Prior to the hypotheses test, the first test of the validity of the actual and actual reliability test is conducted. The results of the questionnaire data that has been distributed to 100 respondents using SPSS can be seen in Table 4.

Table 4: Result of validity actual test and reliability actual test

\begin{tabular}{|c|c|c|c|}
\hline Variable & Item & r-calculated & $\begin{array}{c}\text { Cronbach's } \\
\text { Alpha }\end{array}$ \\
\hline \multirow{4}{*}{ Usefulness } & U1 & 0.751 & \multirow{4}{*}{0.869} \\
\hline & $\mathrm{U} 2$ & 0.788 & \\
\hline & U3 & 0.642 & \\
\hline & $\mathrm{U} 4$ & 0.712 & \\
\hline \multirow{4}{*}{ Ease of Use } & EU1 & 0.716 & \multirow{4}{*}{0.887} \\
\hline & EU2 & 0.813 & \\
\hline & EU3 & 0.779 & \\
\hline & EU4 & 0.722 & \\
\hline \multirow{4}{*}{ Risk } & R1 & 0.642 & \multirow{4}{*}{0.682} \\
\hline & $\mathrm{R} 2$ & 0.384 & \\
\hline & R3 & 0.531 & \\
\hline & $\mathrm{R} 4$ & 0.708 & \\
\hline \multirow{4}{*}{ Trust } & $\mathrm{T} 1$ & 0.384 & \multirow{4}{*}{0.637} \\
\hline & $\mathrm{T} 2$ & 0.443 & \\
\hline & $\mathrm{T} 3$ & 0.388 & \\
\hline & $\mathrm{T} 4$ & 0.554 & \\
\hline \multirow{4}{*}{$\begin{array}{l}\text { Behavior } \\
\text { Intention }\end{array}$} & BI1 & 0.506 & \multirow{4}{*}{0.735} \\
\hline & $\mathrm{BI} 2$ & 0.611 & \\
\hline & $\mathrm{BI} 3$ & 0.549 & \\
\hline & $\mathrm{BI} 4$ & 0.451 & \\
\hline
\end{tabular}

After performing the actual test the validity and reliability of actual, the next will be tested for normality that is testing the normal data distribution conducted with one sample KolmogorovSmirnov Test. Decisions will be obtained as follows:

1. If Asymp.Sig. $<0.05$ then the regression model are not normally distributed.

2. If Asymp.Sig. $>0.05$ then the regression model with normal distribution.

Results of the test of normality can be seen in Table 5 . 
Table 5: Normality Test

\begin{tabular}{|l|c|}
\hline \multicolumn{1}{|c|}{ Variable } & Asymp. Sig. \\
\hline Usefulness & 0.113 \\
\hline Ease of Use & 0.066 \\
\hline Risk & 0.069 \\
\hline Trust & 0.085 \\
\hline Behavior Intention & 0.2 \\
\hline
\end{tabular}

From the statistics table above shows that the regression model for the variable of interest using internet banking normal distribution with Asymp. Sig. (0.113)> 0.05; for the perception of the usefulness of normally distributed variables with Asymp. Sig. $(0.066)>0.05$; for normally distributed variables perceived ease with Asymp. Sig. (0.069)> 0.05; for normally distributed variables risk perception with Asymp. Sig. (0.085)>0.05; and for normally distributed variables with Asymp confidence. Sig. (0.200)>0.05. Therefore, it can be concluded that these variables declared normal distribution. After these variables are expressed in normal distribution through normality test results, then after that it will test the hypothesis that the results can be seen in Table 6.

Table 6: Hypothesis Test

\begin{tabular}{|l|c|c|c|}
\hline \multicolumn{1}{|c|}{ The Influence of Inter Variable } & $\begin{array}{c}\text { Coefficient of } \\
\text { Regretion }\end{array}$ & t calculated & Sig. \\
\hline H1: Usefulness $\rightarrow$ Behavior Intention & 0.213 & 2,569 & 0.012 \\
\hline H2: Ease of Use $\rightarrow$ Behavior Intention & 0.212 & 2,714 & 0.008 \\
\hline H3: Risk $\rightarrow$ Behavior Intention & 0.096 & 1,398 & 0.165 \\
\hline H4: Trust $\rightarrow$ Behavior Intention & 0.221 & 2,289 & 0.024 \\
\hline
\end{tabular}

From the table above, the following equation is derived:

$$
Y=A+b_{1} x_{1}+B_{2} X_{2}+B_{3} X_{3}+B_{4} X_{4}+e
$$

From table 6, the value of the constant A is computed and it is 4.088. Therefore, it can be obtained regression formula as follows:

$$
Y=4.088+0.213 X_{1}+0.212 X_{2}+0.96 X_{3}+0.221 X_{4}+e
$$

\subsection{Usefulness Influence on Behavioral Intention}

Regression coefficient for influence between Usefulness to Behavior Intention of 0.213 and is positive, it indicates that the Usefulness has a direct relationship with the Behavior Intention. This means that each increase of one unit Usefulness Behavior Intention then the variable would increase by 0.213 assuming that the variable Ease of Use, Risk, and Trust is fixed. Furthermore, look at the column sig. for influence between Usefulness to Behavior Intention is equal to 0.008 . Sig. smaller than the probability value of 0.05 or value $0.008<0.05$, it can be draw a conclusion that there is influence between Ease of Use to Behavior Intention. Further see t-count-value 2.714 greater than the t-tables worth 1,984 it can be concluded that the Usefulness has contributed to Behavior Intention. Positive values indicate that the Usefulness t have a direct relationship with the Behavior Intention. So it can be concluded that the Usefulness has a significant influence on Behavior Intention. If the view of the work of the respondents, it appears that this type of work is the most self-employed, where such work demands speed in the transaction. This study resulted in the finding that Usefulness direct positive effect on Behavior Intention. The result supports previous findings made by Davis et al (1989). This can be explained by the idea that someone would use the Internet Banking which enables them to increase their productivity in terms of time 
and cost savings, the ability to transact online banking transactions at any time without having to perform banking transactions at the bank physically.

\subsection{Influence of Ease of Use to Behavior Intention}

Regression coefficient for influence between Ease of Use to Behavior Intention of 0.212 and is positive, it indicates that the Ease of Use has a direct relationship with the Behavior Intention. This means that each increase of one unit Usefulness Behavior Intention then the variable would increase by 0.212 assuming that the variable Usefulness, Risk, and Trust is fixed. Furthermore, look at the column sig. for influence between Ease of Use to Behavior Intention is equal to 0.012. Sig. smaller than the probability value of 0.05 or value $0.012<0.05$, it can be draw a conclusion that there is influence between Usefulness to Behavior Intention. Further see t-count that is worth 2,569 greater than the t-tables worth 1,984 it can be concluded that the Usefulness has contributed to Behavior Intention. Positive values indicate that the Usefulness t have a direct relationship with the Behavior Intention. So it can be concluded that the Usefulness has a significant influence on Behavior Intention. Ease of Use has also been shown to have a significant impact on Behavior Intention. The result corroborates the findings Davis et al (1989). If one considers that Internet banking is easy to use, so they feel that they just need a little effort to operate the system and will use this service. Also visible from the respondent's educational level that the majority of high school graduates and just over 50 years old, Ease of Use influence on them because they are a little difficult to learn to use new technologies. These findings show that a technology can be accepted by a person if the technology has benefits that are comparable to the ease of operation, it can be seen from the figure is almost the same value. This is supported by the profile of the respondents where the majority of respondents are entrepreneurs aged over 50 years with an education that is not too high, which they desperately need speed and practicality in the deal, but they do not want a complicated undertaking in studying or operate technology Internet Banking. Although they all have Internet Banking at other banks but every bank has a way different operations so that they hope will be the operation of Internet Banking at the bank is not very different from other banks Internet banking in general.

\subsection{Risk influence on Behavior Intention}

Regression coefficient for influence between Risk Behavior Intention to simply amounted to 0.096 but still is positive, it indicates that the risk has a direct relationship with the Behavior Intention. This means that each increase of one unit of the Risk Behavior Intention variable will increase by 0.096 assuming that the variable Usefulness, Ease of Use, and the Trust is fixed. Furthermore, look at the column sig. for influence between Usefulness to Behavior Intention is equal to 0.165 . At this hypothesis sig. was greater than the probability value of 0.05 or 0.165 values $>0.05$. It means that there is no risk to the influence of Behavior Intention. Further see t-count-value 1.398 is smaller when compared to the t-tables worth 1,984 it can be concluded that the risk does not contribute to Behavior Intention. Positive $\mathrm{t}$ value indicates that the risk has a direct relationship with the Behavior Intention. So it can be concluded that the risk does not have a significant influence on Behavior Intention but still has a unidirectional relationship. These findings show that the respondents are not ready with the risks faced, such as the findings Susanto et al (2013) who said that customers in Indonesia are still not sure in terms of security. It could be because the respondents were still not so mastered the technology of information that causes them less confident about the security of the facility. It is not only in Indonesia, in Zimbabwe if seeing the findings of Chitungo and Munongo (2013) shows that there is a fairly strong negative correlation between risk which is feared to use Internet Banking. Risk is one of the important factors that should be focused when designing and developing the Internet Banking service. Therefore, for the banks which provide Internet Banking should give more attention to a higher level of security in delivering these services. Even banks that service providers must continue to innovate and offer security or convince customers better and to take advantage of applications that can be relied upon 
to increase the level of confidence in the Internet Banking facilities. From the research Chitungo and Munongo (2013) also explained that they are worried about the uncertainty of such a loss problems due to hacking and information theft and this is avoided by the rural people there because they did not dare to accept the risk.

If it is associated with the study, was sufficient to support a reason if you see the profile of respondents from this study, because of the profile of the respondents is seen that most respondents are high school graduates that they do not seem overly master information technology. It can also be seen from the calculation of the mean and standard deviation, especially on the fourth item questionnaire, which reads "security issue does not affect the use of Internet Banking". Most respondents replied neutral or less agree.

\subsection{Effect of Trust on Behavior Intention}

Regression coefficient for influence between the Trust on Behavior Intention of 0.221 and is positive, it indicates that the Trust has a direct relationship with the Behavior Intention. This means that each increase of one unit of the Trust Behavior Intention variable will increase by 0.221 assuming that the variable Usefulness, Ease of Use, and Risk is fixed. Furthermore, look at the column sig. for influence between Ease of Use to Behavior Intention is equal to 0.024. Sig. smaller than the probability value of 0.05 or value $0.012<0.05$, it can be draw a conclusion that there is influence between the Trust on Behavior Intention. Further see t-count-value 2.289 greater than the t-tables worth 1,984 it can be concluded that the Trust has contributed to Behavior Intention. Positive $t$ value indicates that the Trust has a direct relationship with the Behavior Intention. So it can be concluded that the Trust has a significant influence on Behavior Intention. Therefore, the respondent does not have the experience of using Internet Banking at the bank, then that will be the confidence of the respondents is the physical factors of the bank (Montazemi and Saremi, 2013). Majority of the respondents in this study is the customers who had been saving for more than two years at the bank and it is proved that most respondents were loyal customers at this bank. Although the balance of their savings ranged only between one and ten million, it could be due to the facility to transact still very low which is expected by the Internet Banking facility is these customers can further improve the balance.

\section{Conclusions}

This study has presented an analysis to see how the influence of Usefulness, Ease of Use, Risk, and Trust on Behavior Intention in the use of Internet Banking. There are four variables studied which are variables that positively affects Behavior Intention just Usefulness, Ease of Use, and Trust. Meanwhile the risk factor has no significant influence. Judging from the results of this study, respondents prefer the factors benefit from the provision of Internet Banking. After the benefit factor, factor is the ease of the next sequence in which the use of a facility not only benefits are expected, but ease of use is also expected. Although the respondents are users of Internet Banking at other banks, but they are still worried about the risks they will face, although they are the majority is the old customers at the bank and had enough trust with the quality of banks or in other words they are loyal customers. It may be because the facility has never existed in the bank, so that customers can see the track record against the use of Internet Banking at the bank.

Managerial implications can be presented based on the results of research that Usefulness is a variable that affect Behavior Intention in the use of Internet Banking. This suggests that the expectations of respondents to the provision of Internet Banking facility at the bank are very high. But the bank can not simply provide the Internet Banking facility without considering the ease of operation for its customers. If the views of risk factors which respondents are still alarming, the banks are expected to pay more attention to these factors and be able to convince customers against risk guarantee that will be faced by the customers. With the Internet Banking facility as well as pay attention to these aspects of the bank is expected to be more satisfying customers and can increase the confidence of its customers to be more loyal in the bank. 


\section{Acknowledgement}

The authors would like to thanks Universitas Putra Indonesia "YPTK" Padang for supporting this research.

\section{References}

Davis, F.D. (1989). Perceived Usefulness, Perceived Ease of Use, and User Acceptance of Information Technology. MIS Quarterly. Vol. 13 No. 3. pp. 319-340.

Amin, A. (2007). Internet Banking Adoption Among Young Intellectuals. Journal of Internet Banking and Commerce. Vol. 12 No. 3.

Brown, T.J., Mowen, J.C., Donavan, D.T., dan Licata, J.W. (2002). The Customer Orientation of Service Workers: Personality Trait Effects on Self and Supervisor Performance Ratings. Journal of Marketing Research. Vol. 39. pp. 110-119.

Chavan, J. (2013). Internet Banking - Benefits and Challenges in an Emerging Economy. International Journal of Research in Business Management (IJRBM). Vol. 1 No. 1. pp. 19-26.

Chitungo, S.K., dan Munongo, S. (2013). Extending the Technology Acceptance Model to Mobile Banking Adoption in Rural Zimbabwe. Journal of Business Administration and Education. Vol. 3 No. 1. pp. 51-79.

Chowdhury, M.S., dan Ahmad, N. (2011). Factor Affecting Consumer Participation In Online Shopping In Malaysia: The Case of University Students. European Journal of Business and Economics. Vol. 5. pp. 49-53.

Dowling, G.R., dan Staelin, R. (1994). A Model of Perceived Risk and Intended Risk-Handling Activity. Journal of Consumer Research. Vol. 21 No. 1. pp. 119-134.

Gerrard, P., Cunningham, B., dan Devlin, J.F. (2006). Why Consumers are not Using Internet Banking: A Qualitative Study. Journal of Services Marketing. Vol. 20 No. 3 pp. 160 - 168.

Kesharwani, A., dan Bisht, S.S. (2012). The Impact of Trust and Perceived Risk on Internet Banking Adoption in India: An Extension of Technology Acceptance Model. International Journal of Bank Marketing, Vol. 30 No. 4, pp. 303-322.

Koo, C., Wati, Y., dan Chung, N. (2013). A Study of Mobile and Internet Banking Service: Applying for IS Success Model. Asia Pasific Journal of Information Systems. Vol. 23 No. 1. pp. 431-449.

Lichtenstein, S., dan Williamson, K. (2006). Understanding Consumer Adoption of Internet Banking: An Interpretive Study in The Australian Banking Context. Journal of Electronic Commerce Research. Vol. 7 No. 2. pp. 50-66.

Mishra, S.K., dan Sahoo, D.P., (2013). Mobile Banking Adoption and Benefits Towards Customers Service. Special Issue of International Journal on Advanced Computer Theory and Engineering (IJACTE). Vol. 2 No. 1. pp. 2319-2526.

Montazemi, A.R., dan Saremi, H.Q. (2013). Factors Affecting Internet Banking Pre-Usage Expectation Formation. Hawaii International Conference on System Sciences. Vol. 46. pp. 4.666-4.675.

Muzividzi, D.K., Mbizi, R., Mukwazhe, T. (2013). An Analysis of Factors That Influence Internet Banking Adoption Among Intellectuals: Case of Chinhoyi University of Technology. Interdisciplinary Journal of Contemporary Research in Business. Vol. 4 No. 11. pp. 350-369.

Prasarnphanich, P. (2007). Does Trust Matter to Develop Customer Loyalty in Online Business?. Special Issue of the International Journal of the Computer, the Internet and Management. Vol.15 No. SP4. pp. 23.1-23.7.

Safeena, R., Date, H., Hundewale, N., dan Kammani, A. (2013). Combination of TAM and TPB in Internet Banking Adoption. International Journal of Computer Theory and Engineering. Vol. 5 No. 1. pp. 146-150.

Susanto, A., Lee, H., Zo, H., dan Ciganek, A.P. (2013). Factors Affecting Internet Banking Success: A Comparative Investigation between Indonesia and South Korea. Journal of Global Information Management. Vol. 21 No.2. pp: 72-95.

Tan, M., dan Teo, T.S.H. (2000). Factor Influencing the Adoption of Internet Banking. Journal of the Association for Information Systems. Vol. 1 No. 5. 
Triandis, H.C. (1989). The Self and Social Behavior in Differing Cultural Contexts. Psychological Review. Vol. 96 No. 3. pp. 506-520.

Verhagen, T., and Heidjen, H. (2004). Online store image: conceptual foundations and empirical measurement. Information and Management. Vol. 41. pp. 609-617.

Yi, M.Y., dan Hwang, Y. (2003). Predicting The Use of Web-Based Information Systems: Self-Efficacy, Enjoyment, Learning Goal Orientation, and The Technology Acceptance Model. Int. J. HumanComputer Studies. Vol. 59. pp-431-449. 


\section{APPENDIX}

Profile of Respondents:

1. Do you have savings in the bank other than the bank?
$\square$ Yes
$\square$ No

2. Do you belong to users of Internet Banking facility?
$\square$ Yes
$\square$ No

If you answer "Yes", please continue with the next question.

3. Gender:

$\square$ Male $\quad \square$ Female

4. Age:
$\square$ 17-30 years
$\square>50$ years
$\square$ 31-50 years

5. Education:
$\square$ High School
$\square$ Master Degree and Doctoral Degree
$\square$ Bachelor Degree
$\square$ Other

6. Occupation:
$\square$ Student / Undergraduate Student $\square$ Entrepreneur
$\square$ Employee

7. Old Being Customer:
$\square<6$ months
$\square$ 1-2 years
$\square$ 6-12 months
$\square>2$ years

8. Average Monthly Balance (IDR):
$\square<1$ million
$\square$ 10-100 million
$\square$ 1-10 million
$\square>100$ million

\begin{tabular}{|c|l|c|c|c|c|c|}
\hline \multirow{2}{*}{ No. } & \multicolumn{1}{|c|}{ Question } & \multicolumn{3}{|c|}{ Answer } \\
\cline { 3 - 6 } & \multicolumn{1}{|c|}{ USEFULNESS } & $\mathbf{1}$ & $\mathbf{2}$ & $\mathbf{3}$ & $\mathbf{4}$ & $\mathbf{5}$ \\
\hline \multicolumn{3}{|c|}{} & \multicolumn{1}{|c|}{$\begin{array}{l}\text { Internet Banking will enhance my performance in conducting } \\
\text { banking transactions. }\end{array}$} & & & \\
\hline 2. & $\begin{array}{l}\text { Internet Banking will make it easier for me to carry out } \\
\text { banking transactions. }\end{array}$ & & & & \\
\hline 3. & $\begin{array}{l}\text { I will find the benefits of Internet Banking in doing my } \\
\text { banking transactions. }\end{array}$ & & & & \\
\hline 4. & $\begin{array}{l}\text { Internet Banking is able to improve the efficiency of my } \\
\text { banking activities. }\end{array}$ & & & & & \\
\hline
\end{tabular}




\section{EASE OF USE}

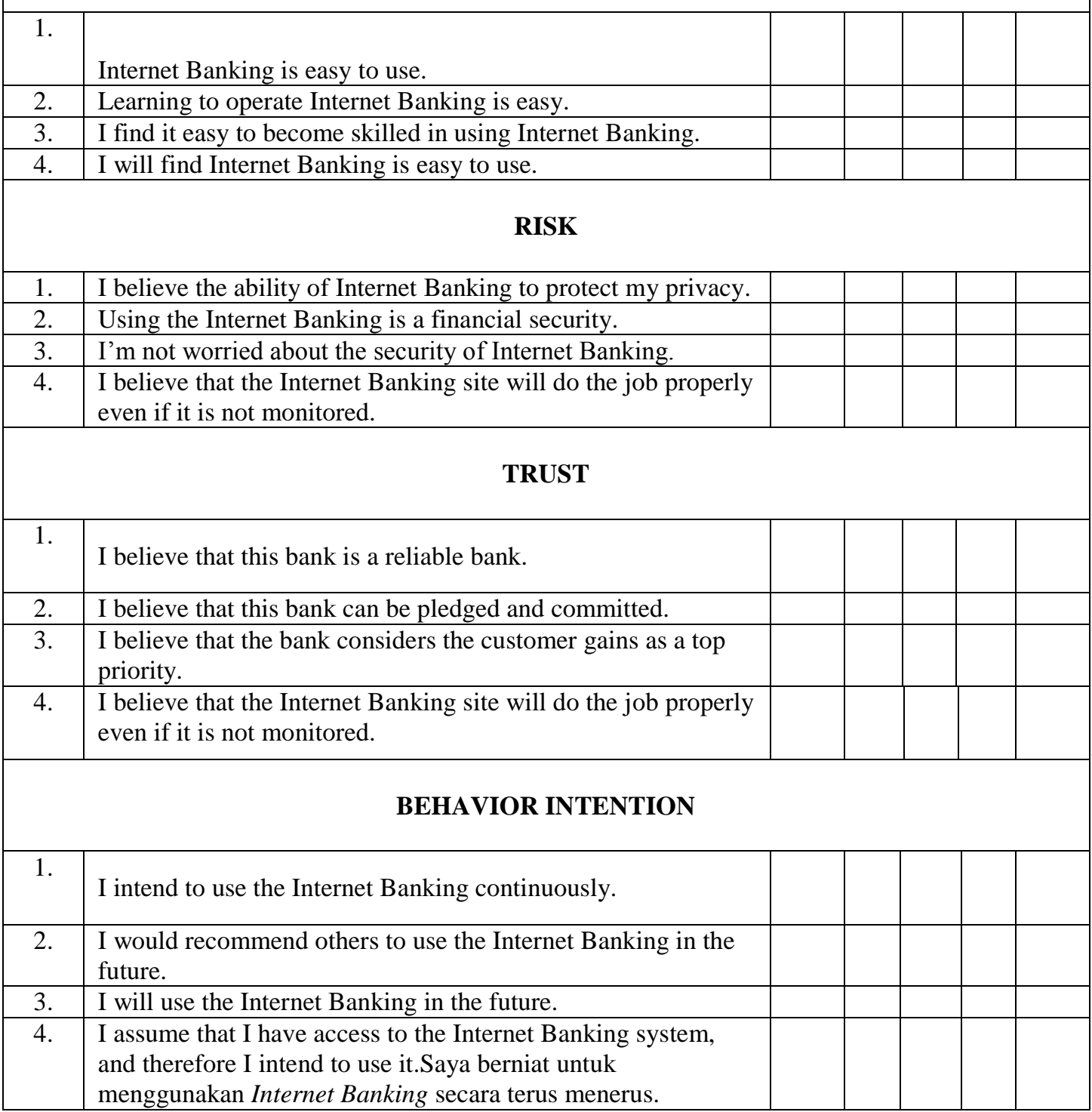

